\title{
$\mathrm{PHC}$ 에너지파일의 열응력에 따른 축하중-침하 수치해석
}

\section{Numerical Analysis of Thermal Effect on Axial Load and Pile Settlements in PHC Energy Piles}

\author{
이 대 수 ${ }^{1}$ Lee, Dae-Soo \\ 임 현 성 ${ }^{3}$ Lim, Hyun-Sung
}

\author{
민 혜 선 ${ }^{2}$ Min, Hye-Sun \\ 정 상 섬 ${ }^{4}$ Jeong, Sang-Seom
}

\begin{abstract}
This study investigates the effect of thermal stress on axial load and pile settlement of PHC energy piles. A series of numerical analyses were performed by controlling major influencing parameters such as pile arrangement, pile spacing, end-bearing condition, soil condition and pile cap stiffness. It is found that the characteristics of pile-load transfer are significantly affected by seasonal operation mode (i.e., cooling and heating) throughout the year. Also, the axial load under thermal loading increases with increasing the pile spacing. The settlement of the pile in sand is larger than that in clay because of the thermal stress generated. It is also found that thermal stress highly influences on the end-bearing pile, corner pile and rigidity of pile cap.
\end{abstract}

\section{요지}

본 논문에서는 열응력에 따른 $\mathrm{PHC}$ 에너지파일의 축하중과 침하량의 변화를 수치해석을 통하여 분석하였다. 이를 위해 $3 \times 3,5 \times 5$ 배열 군말뚝 형태의 에너지파일을 말뚝 간격과 배치, 지반조건, 말뚝의 선단지지조건 및 말뚝 캡의 강성도 등의 조건으로 구분하여 수치해석을 수행하였다. 본 연구 결과 말뚝 중심 간격이 클수록 온도변화에 따른 말뚝의 축하중 차이가 크게 나타났고, 사질토지반이 점성토지반 보다 온도변화에 의한 침하량의 변화가 크게 나타났 다. 또한, 에너지파일이 모서리부에 위치할 때 말뚝의 축하중 차이가 가장 크게 나타났으며, 말뚝의 선단이 암반에 지지된 경우 온도변화에 의한 축하중 변화가 더 크게 발생하여 침하량이 감소하는 것을 확인하였다. 말뚝 캡의 강성도 에 대한 영향은 말뚝 캡의 강성이 커질수록 온도변화에 의한 침하량이 감소하는 것으로 나타났다.

Keywords : Energy piles, Group piles, Cooling and heating, Pile spacing, Pile arrangement

\section{1. 서 론}

최근 세계적으로 부존된 화석연료의 고갈로 인한 에 너지 위기를 극복하고, 온실가스에 의한 기후변화 문제
를 해결하기 위해 다양한 방안들을 모색하고 있다. 대부 분의 선진국들은 에너지 절약사업과 효율향상 위주로 정책의 틀을 짜고 있으며, 신재생에너지의 이용, 저탄소 연료 사용 확대 등에도 관심을 갖고 적극적으로 추진하

1 정회원, 한전전력연구원 수석연구원 (Member, Chief Researcher, KEPCO Research Institute)

2 정회원, 한국환경공단 연구원 (Member, Researcher, Korea Environment Corporation)

3 정회원, 연세대학교 토목환경공학과 석사과정 (Member, Graduate Student, Dept. of Civil and Environmental Eng., Yonsei Univ.)

4 정회원, 연세대학교 토목환경공학과 교수 (Member, Prof., Dept. of Civil and Environmental Eng., Yonsei Univ., Tel: +82-2- 2123-2807, Fax: +82-2-2123-8378, soj9081@yonsei.ac.kr, 교신저자)

* 본 논문에 대한 토의를 원하는 회원은 2013년 11월 30일까지 그 내용을 학회로 보내주시기 바랍니다. 저자의 검토 내용과 함께 논문집에 게재하여 드립니다. 
고 있다. 국내에서도 저탄소형 사회 구현과 녹색 성장이 라는 두 가지 국가 정책을 실현하기 위해 대체에너지를 확대, 보급하기 위한 노력을 하고 있다. 특히 신재생에 너지의 개발·이용·보급 촉진법을 책정함으로써 에너지 원을 다양화하고 에너지의 안정적인 공급, 에너지 구조 의 환경 친화적 전환, 온실가스 배출 저감을 추진하고 있다. 신재생에너지 중 지열에너지는 다른 대체에너지 에 비하여 초기 투자비가 적게 들고 소규모 이용이 가능 하며, 지반을 하나의 거대한 에너지 저장창고개념으로 친환경적이고 반영구적인 에너지 자원으로 볼 수 있다. 이 중 지열냉난방시스템은 가장 열효율이 높아 활용도 가 높으며 반영구적, 친환경적 시스템으로 보고되고 있 다(Environmental Protection Agency, 1993). 그러나 기 존 냉난방 시스템과 비교하여 지중열교환기 시공을 위 한 천공 비용에 의해 초기 투자비가 높다는 단점이 있 다. 이러한 문제점을 해결하기 위해 건물의 기초에 지중 열교환기를 설치하여 지열냉난방시스템으로 활용하는 연구가 이루어지고 있다. 에너지파일은 콘크리트말뚝 내부에 열교환기를 설치하는 형태의 말뚝을 말하며, 지 열에너지 또는 건물에서 발생하는 열에너지를 말뚝에 축적하여 에너지로 활용하는 기술이다. 이는 말뚝의 구 조적인 지지능력과 콘크리트의 열 축적능력을 동시에 활용할 수 있는 장점이 있다. 이에 에너지파일의 성능 평가 및 현장 실험을 통해 열교환기의 길이, 그라우팅 재료, 열교환기 파이프 간격의 영향에 대한 에너지파일 의 설치 조건에 따른 열효율 분석에 대한 연구가 수행되 고 있다.

국내에서 실시한 에너지파일의 시스템 개발 관한 연 구는 고성능 저가형 지중 열교환기 개발 연구(Ministry of Trade, Industry and Energy, 2006)와 중공 말뚝을 이 용한 지열 냉난방 시스템 개발에 관한 연구(Baek, 2004) 등이 있으며, 최근 지열 냉난방 시스템 활용을 위한 친 환경 수직형 지중 열교환 시스템의 개발에 관한 연구 (Ministry of Land, Infrastructure and Transport, 2010)가 수행되었다. 그리고 에너지파일의 성능 분석 및 열효율 에 대한 연구로는 유동해석 프로그램인 Fluent를 이용한 에너지파일의 속채움재 종류, 말뚝 종류, 열전달 특성에 대한 연구(Woo et al., 2007; Jeong et al., 2010; Song, 2011; Min et al., 2011)가 수행되었으며 유형규(2008)는 현장 실험을 수행하여 성능을 평가하고, 계측치를 바탕 으로 수치해석을 통한 검증을 수행하였다.

외국의 경우 $\mathrm{PHC}$ 말뚝 형태의 마찰말뚝으로 시공된
에너지파일의 열효율을 현장실험을 통하여 측정하였으 며(Hamada et al., 2007), 현장 실험 및 수치해석을 통해 에너지파일의 순환수 온도에 따른 말뚝의 수축, 팽창거 동과 하중전이기구의 변화에 대한 연구가 수행되었다 (Bourne-webb et al., 2009; Knellwolf et al., 2011; Laloui 등, 1999).

에너지파일은 설치 후 상부 구조물의 하중이 가해지 고 에너지파일이 운용되면 온도차에 의해 추가적인 열 응력이 발생하게 된다. 열응력이 발생하면 말뚝의 축하 중 전이 양상과 주면마찰력의 차이가 발생하여 이에 대 한 구조적 거동 분석이 필요하다(Laloui et al., 1999). 그 러나 에너지파일의 냉난방 순환에 따른 열응력의 발생 과 구조적 검토에 대한 국내 선행연구는 거의 전무한 실정이다. 따라서 본 논문에서는 군말뚝에서 에너지파 일의 배치 및 말뚝 간격, 지반조건 그리고 말뚝 캡의 강 성도 및 선단지지조건에 따른 구조적 거동을 파악하기 위하여 COMSOL Multiphysics v.4.2a(2011)를 이용한 수치해석을 실시하였다.

\section{2. 에너지파일의 구조거동 이론}

국내 에너지파일은 대체로 콘크리트로 만들어진 말 뚝 내부에 열교환기가 설치되는 형태를 가지며, 내부 열 교환기에 흐르는 순환수의 온도에 따라 말뚝의 온도가 증가 또는 감소하게 되어 말뚝은 수축팽창 거동을 하게 된다. 이 때 말뚝 상부 구조물의 하중 외에 말뚝에 작용 되는 추가적인 열응력과 재료적 성질에 의해 말뚝은 냉 방과정에서 팽창하고 난방과정에서 수축하여 말뚝과 주변 지반과의 상대적인 변위가 발생하게 된다(Min et al., 2010). Fig. 1은 열응력에 의한 구조적 거동 모식도 를 나타낸다. 동절기 난방(heating)시에는 말뚝이 수축 하기 때문에 말뚝의 축하중은 감소를 한다. 반면에 말뚝 의 주면마찰력 $\left(\mathrm{Q}_{\mathrm{s}}\right)$ 은 말뚝의 두부로 갈수록 증가하고 말뚝의 선단으로 갈수록 감소한다. 반대로 하절기 냉방 (cooling)시에는 말뚝이 팽창하기 때문에 축하중은 증가 하고 반면에 말뚝의 주면마찰력은 말뚝의 두부로 갈수 록 감소하고, 말뚝의 선단으로 갈수록 증가한다. 추가되 는 열응력을 고려한 에너지파일의 지지력 산정식은 식 (1)과 같다(Knellwolf et al., 2011).

$$
Q_{p}+\sum_{\text {base }}^{\text {head }} Q_{s} \geq P+\Delta T \cdot \alpha \cdot E_{\text {pile }} \cdot A
$$




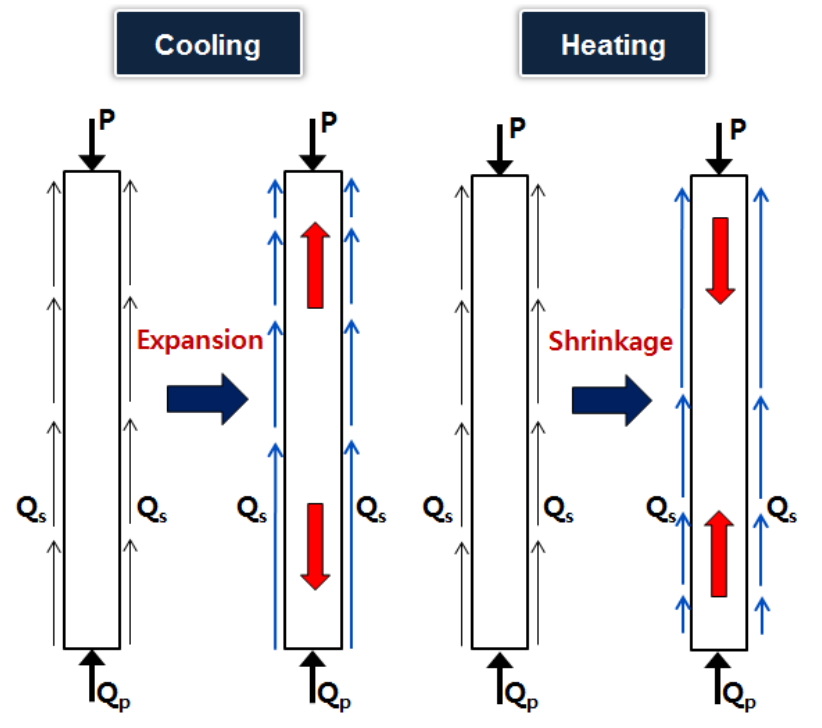

Fig. 1. Concept of mechanical behavior by thermal stress

여기서, $Q_{p}=$ 말뚝의 선단지지력

$Q_{s}=$ 말뚝의 주면마찰력

$P=$ 상부 하중

$\triangle T=$ 온도 변화량

$\alpha=$ 열팽창계수

$A=$ 말뚝의 단면적

$E_{\text {pile }}=$ 말뚝의 탄성계수

\section{3. 해석 모델링 및 해석 조건}

\section{1 해석 모델링}

본 연구에서 수행한 수치해석은 총 3 단계로 진행되 었다. 1 단계에서 열전달(Heat Transfer in Solid) 모듈을 이용하여 지반과 말뚝의 초기온도를 설정하고, 2 단계 에서 말뚝에 단계별 하중을 가하였다. 3 단계에서는 말 뚝 내 열교환기에 일정 온도를 가지는 유입수를 순환시 켜 말뚝의 수축팽창거동을 모사하여 말뚝의 하중 전이 양상을 분석하였다. 에너지파일의 수치해석 단계는 Fig. 2 와 같다.

본 논문에서는 군말뚝의 중심 간격에 따른 축하중 변 화와 배열 상태에 따른 응력거동을 확인할 수 있도록 모델링 하였으며, 열응력의 경계는 군말뚝에 영향이 발 생하지 않는 충분한 범위에 대하여 산정하였다. 이 때, 지반은 단일지반으로 Mohr-Coulomb 재료로, 말뚝은 탄 성체로 가정하였다. 수치해석 모델은 Fig. 3 과 같이 $\mathrm{PHC}$

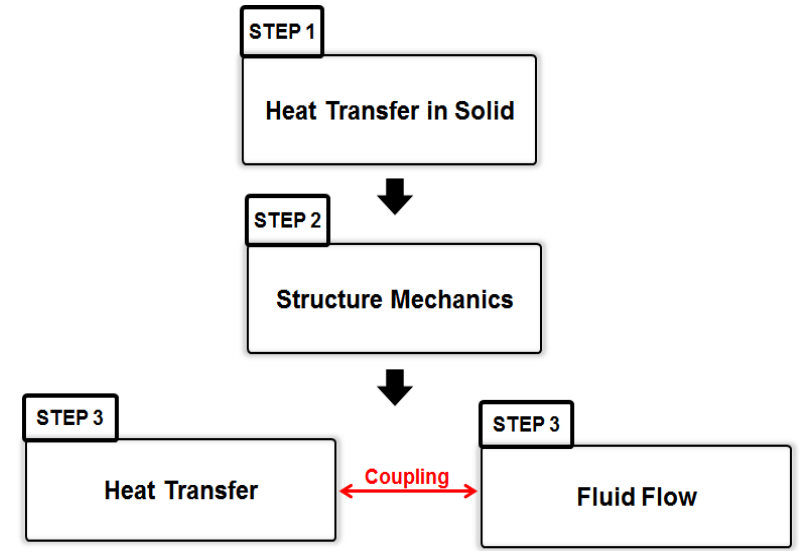

Fig. 2. Numerical analysis steps

말뚝은 외경 $0.5 \mathrm{~m}$, 내경 $0.34 \mathrm{~m}$, 길이 $20 \mathrm{~m}$ 로 설정하였으 며, 열교환기는 실제 사용되는 열교환 파이프의 규격을 모델로 하여 외경 $70 \mathrm{~mm}$, 두께 $5 \mathrm{~mm}$, 총길이 $40.2 \mathrm{~m}$ 의 U자형 HDPE(High density poly-ethelen) 열교환기를 말 뚝별로 독립적인 단일 연결 상태로 배치하였다. 이 때, 열교환기 모델링시 열교환기 두께가 상대적으로 얇기 때문에 해석 프로그램에서 가상의 두께로 가정하여 모 델링하는 방법을 사용하였다. 에너지파일의 단면도와 열교환기의 형상은 Fig. 4 와 같다. 지반의 크기는 말뚝 거동이 경계면의 영향을 받지 않도록 하기 위하여 수평 방향은 말뚝 직경(D)의 11배(11D), 수직 방향은 말뚝 선 단부로부터 말뚝 길이 $(\mathrm{L})$ 의 0.7 배 $(0.7 \mathrm{~L})$ 를 적용하였다 (Wallace et al., 2002, Kim and Jeong, 2011). 말뚝 캡은 수평방향으로 말뚝 직경(D)의 1.5 배(1.5D), 수직방향으 로 $1 \mathrm{~m}$ 를 적용하였다. 지반은 포화된 사질토와 점성토로 구성하였다. 해석의 사용된 지반, 말뚝 캡, 말뚝, 열교환 기 등의 물성치는 일반적인 값을 사용하였으며 Table 1, 2와 같다(Enginneringtoolbox, 2005). 지반의 온도 경계 조건은 Fig. 5와 같이 설정하였다. 에너지파일 운용시 유입수의 속도는 $0.6 \mathrm{~m} / \mathrm{s}$ 로 설정하였고, '8시간 운용'을 기준으로 단기간 동안의 수치해석을 실시하였다(Jeong et al., 2010).

열교환기 내부의 유체흐름은 유체의 속도에 따라서 층류와 난류가 발생할 수 있으나, 본 해석에서는 층류의 흐름으로 가정하였다. 말뚝캡 상부에 작용하는 하중은 등분포하중(uniformly distribution load)으로 설정하여 모 델링하였으며, 말뚝 1 본당 $1,000 \mathrm{kN}$ 으로 가정하여 $3 \times 3$ 배열과 $5 \times 5$ 배열일 경우, 각각 총 작용하중이 $9,000 \mathrm{kN}$, $25,000 \mathrm{kN}$ 을 적용하였다. 


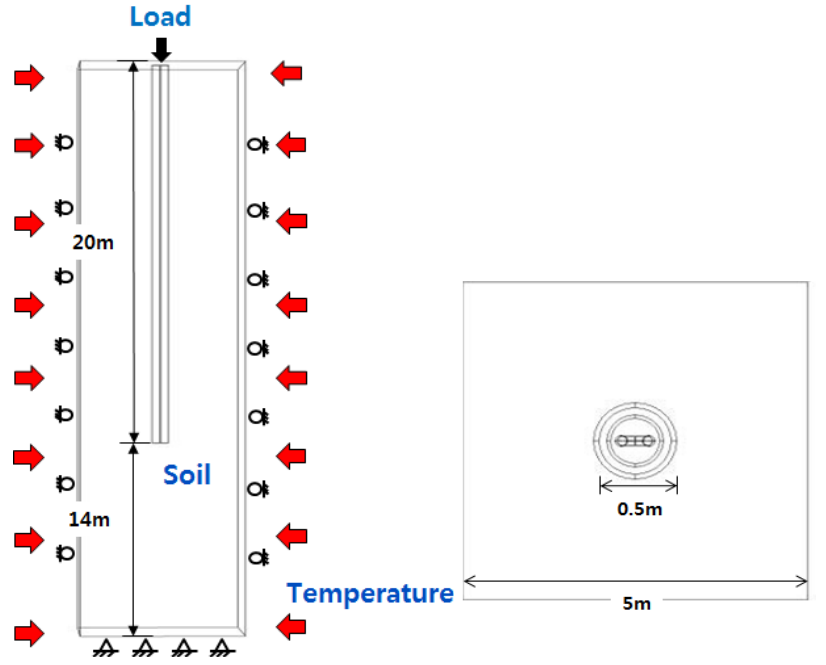

(a) Single pile

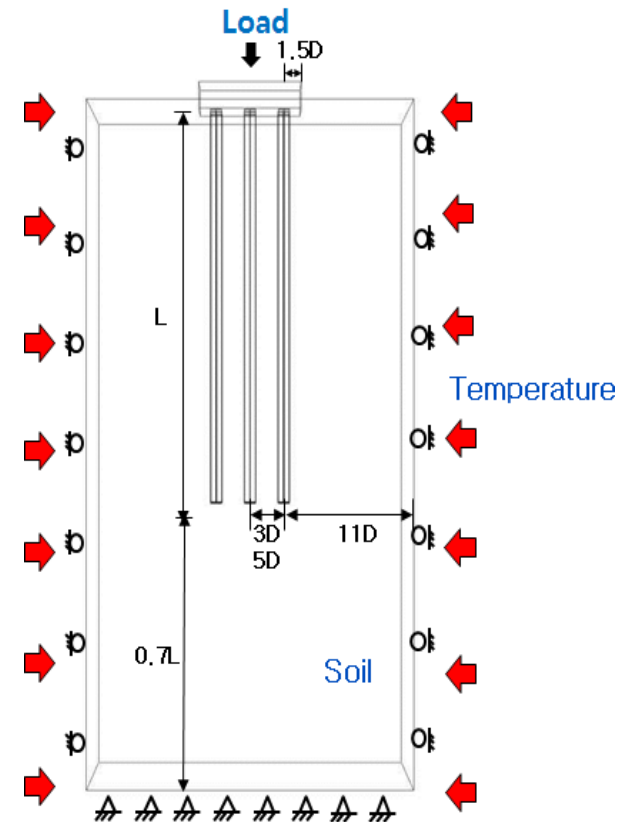

(c) Pile group ( $3 \times 3$ arrangement)

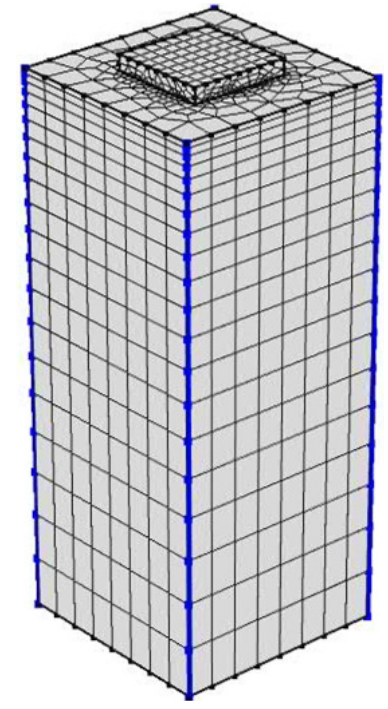

(b) 3D FE Mesh

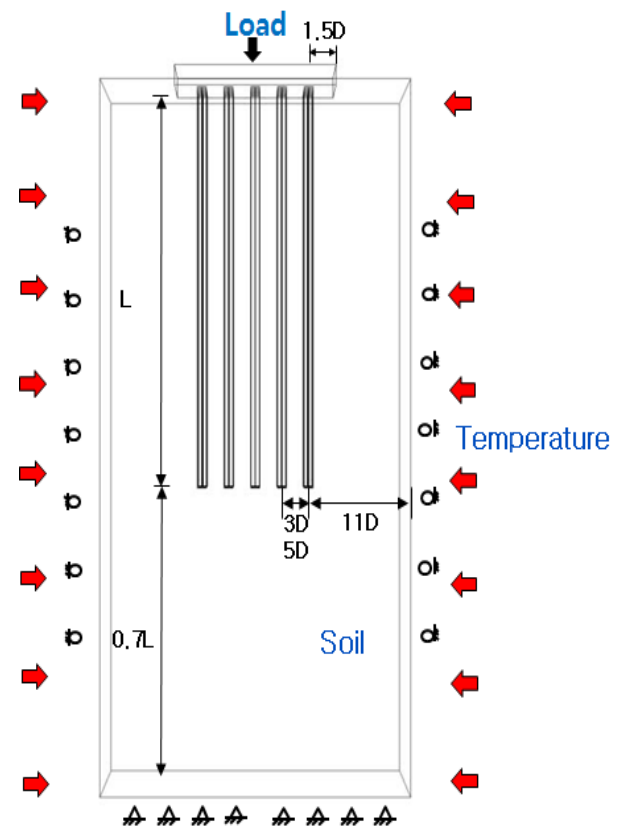

(d) Pile group $(5 \times 5$ arrangement)

Fig. 3. Typical 3D FE mesh and boundary condition

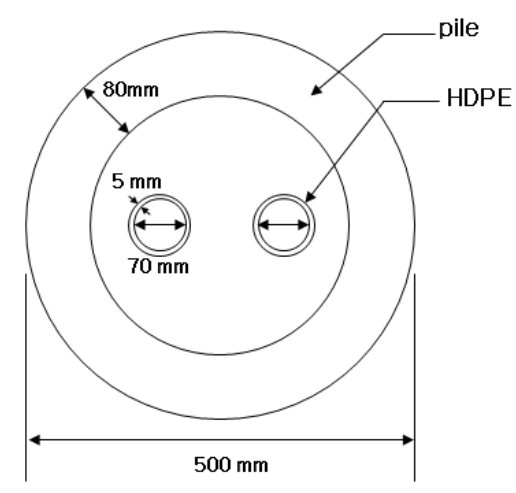

(a) A cross-section of the energy pile

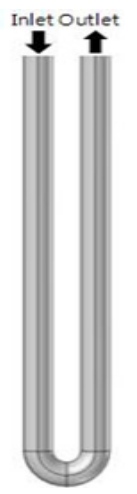

(b) Heat exchanger

Fig. 4. A cross-section of the energy pile and heat exchanger

\section{2 해석 조건}

군말뚝의 중심 간격 및 에너지파일의 배치에 따른 구 조적 거동을 분석하기 위하여 $3 \times 3,5 \times 5$ 군말뚝의 중심 간격을 $3 \mathrm{D}$ 와 $5 \mathrm{D}$ 로 설정하였으며 Fig. 6 과 같이 일부분 을 에너지파일로 설정하고 나머지 부분은 일반 말뚝으 로 설정하였다. 또한, 지반조건에 따른 구조적 거동을 분석하기 위하여 사질토 지반과 점성토 지반으로 나누 어 해석을 수행하였다.

에너지파일이 배치된 군말뚝에서 말뚝선단이 암반에 지지된 경우, 선단지지력 증가로 인한 영향을 알아보고 
Table 1. Mechanical properties (Engineering tool box, 2005)

\begin{tabular}{c|c|c|c|c|c}
\hline & Raft & PHC Pile & Sand & Clay & Rock \\
\hline $\mathrm{E}(\mathrm{MPa})$ & 28,000 & 28,000 & 75 & 5 & 2,500 \\
\hline$\gamma\left(\mathrm{kN} / \mathrm{m}^{3}\right)$ & 24 & 24 & 19 & 18 & 25 \\
\hline $\mathrm{v}$ & 0.2 & 0.2 & 0.3 & 0.3 & 0.3 \\
\hline$\Phi\left({ }^{\circ}\right)$ & - & - & 30 & 20 & 45 \\
\hline $\mathrm{C}(\mathrm{kPa})$ & - & - & 1 & 20 & 10,000 \\
\hline
\end{tabular}

Table 2. Thermal properties (Engineering tool box, 2005)

\begin{tabular}{c|c|c|c|c|c}
\hline & HDPE & PHC Pile & Sand & Clay & Rock \\
\hline Specific Heat $(\mathrm{J} / \mathrm{kg} \cdot \mathrm{k})$ & 525 & 790 & 1400 & 1300 & 1480 \\
\hline Conductivity $(\mathrm{W} / \mathrm{m} \cdot \mathrm{k})$ & 0.4 & 1.62 & 4 & 2.5 & 4.8 \\
\hline
\end{tabular}

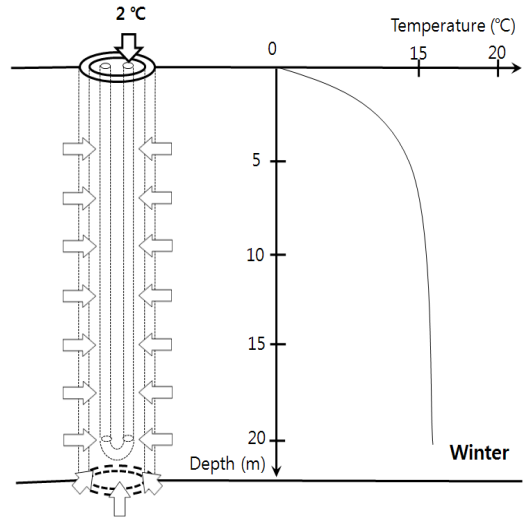

(a) Winter

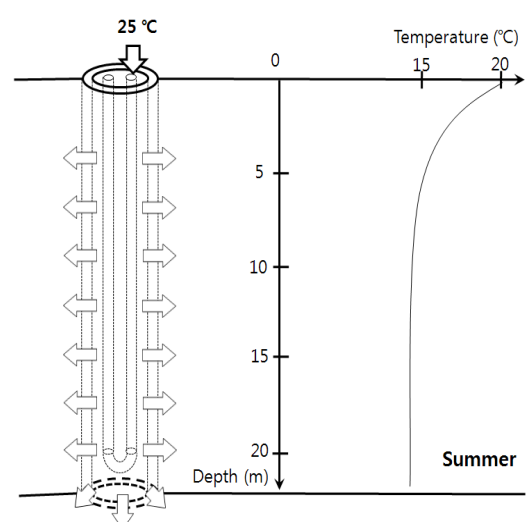

(b) Summer

Fig. 5. Variation of ground temperature profile in summer and winter

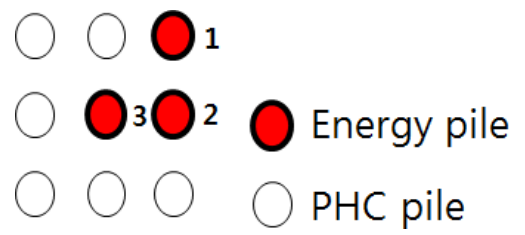

(a) $3 \times 3$ arrangement

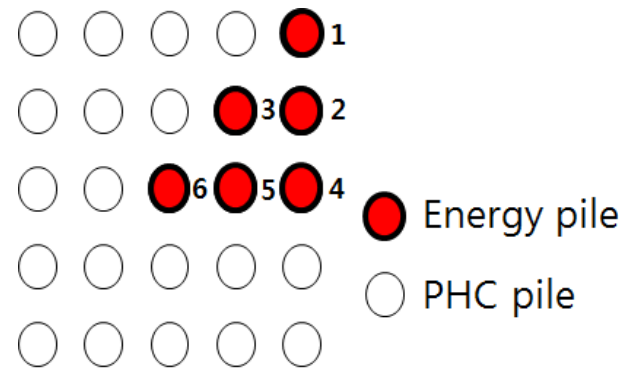

(b) $5 \times 5$ arrangement

Fig. 6. Relative position of energy piles in a group

자 동일한 조건에서 말뚝선단이 암반에 지지된 경우와 지지되지 않은 경우로 나누어 수치해석을 수행하였다. 말뚝의 캡 강성도에 따른 두부침하량의 변화를 알아 보기 위하여 말뚝 캡의 강성도를 조절하여 연성상태와 강성상태로 나누어 수치해석을 수행하였다. 말뚝 캡의 강성도는 식 (2)를 이용하여 강성계수 $\mathrm{K}_{\mathrm{rs}}$ 를 산정하며, $\mathrm{K}_{\mathrm{rs}}$ 의 범위는 0.001 을 완전 연성 상태, 1000 을 완전 강
성 상태로 보고 그 사이 값을 산정한다(Horikoshi and Randolph, 1997). 본 연구에서 사용된 물성을 이용하여 강성계수를 산정한 결과 사질토 지반인 경우 0.496 , 점 성토 지반인 경우 0.768 을 나타내었으며, 이 값을 연성 캡으로 설정하였다. 강성 캡의 경우 $\mathrm{K}_{\mathrm{rs}}=100$ 으로 고정하 고 지반조건 별 캡의 탄성계수를 산정하여 해석에 사용 하였다. 


$$
K_{r s}=5.57 \frac{E_{r}}{E_{s}} \frac{1-\nu_{s}^{2}}{1-\nu_{r}^{2}}\left(\frac{B}{L}\right)^{0.5}\left(\frac{t_{r}}{L}\right)^{3}
$$

\section{4. 에너지파일의 구조적 거동 분석}

\section{1 말뚝 간격 및 배열에 따른 거동 분석}

본 절에서는 $3 \times 3,5 \times 5$ 배열 군말뚝의 말뚝 중심 간 격을 $3 \mathrm{D}, 5 \mathrm{D}$ 로 나누어 수치해석을 수행하여 결과를 분 석하였고, 말뚝 중심 간격에 따라 군말뚝 중 응력이 중 첩되는 범위에 따라 구분하여 각각 1 개의 말뚝을 비교 하여 하중전이양상을 비교하였다.

계절별로 에너지파일이 운용됨에 따라 내부 순환수 의 온도에 의해 말뚝은 수축팽창 거동을 하게 되고, 상 부하중이 가해지는 두부에서 하중전이양상의 가장 큰
차이점을 확인할 수 있다. Fig. 7은 사질토 지반에서 $3 \times$ 3 배열 군말뚝의 말뚝 중심 간격이 $3 \mathrm{D}$ 인 경우 말뚝 위치 별 축하중 분포를 나타낸 것이다. 온도변화가 없을 때, 하중은 무리말뚝의 모서리부에서 $847.8 \mathrm{kN}$ 으로 하중을 가장 크게 받고, 측면부는 $760.4 \mathrm{kN}$, 중앙부는 $606.9 \mathrm{kN}$ 으 로 모서리부에 비해 상대적으로 작은 하중을 받는 것으 로 해석되었다. 이것은 중앙부 말뚝의 주변에서 응력이 중첩되는 현상이 가장 많기 때문인 것으로 판단된다. 하 지만 하절기에는 말뚝이 팽창하면서 온도변화가 발생 하기 전보다 더 큰 하중이 가해지게 되는데, 그 크기는 모서리부에서 $998.3 \mathrm{kN}$ 으로 약 $20 \%$ 증가하는 것으로 나 타났다. 반대로 동절기에는 말뚝이 수축하여 온도변화 가 발생하기 전보다 축하중이 감소하는 것을 확인할 수 있다. Fig. 8 은 말뚝 중심 간격이 $5 \mathrm{D}$ 일 경우 계절별 축하 중을 분포를 나타낸 것이다. 이 경우에도 $3 \mathrm{D}$ 와 마찬가지

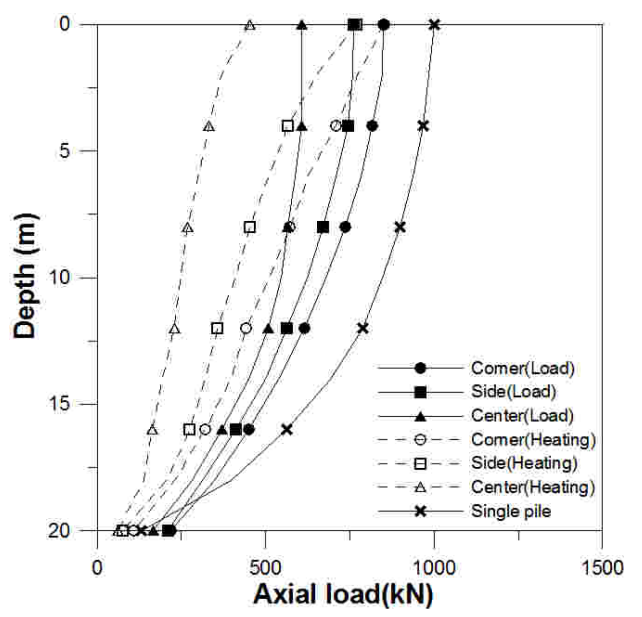

(a) Winter

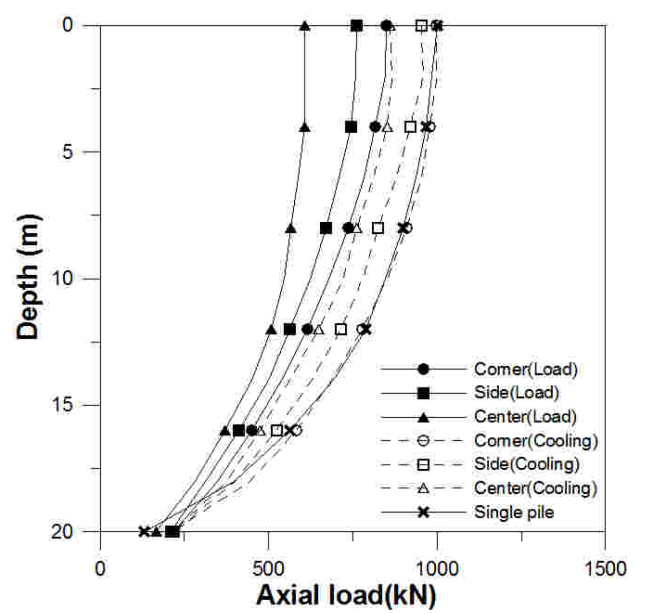

(b) Summer

Fig. 7. Effect of pile spacing on axial load distribution in sand $(3 \times 3,3 d)$

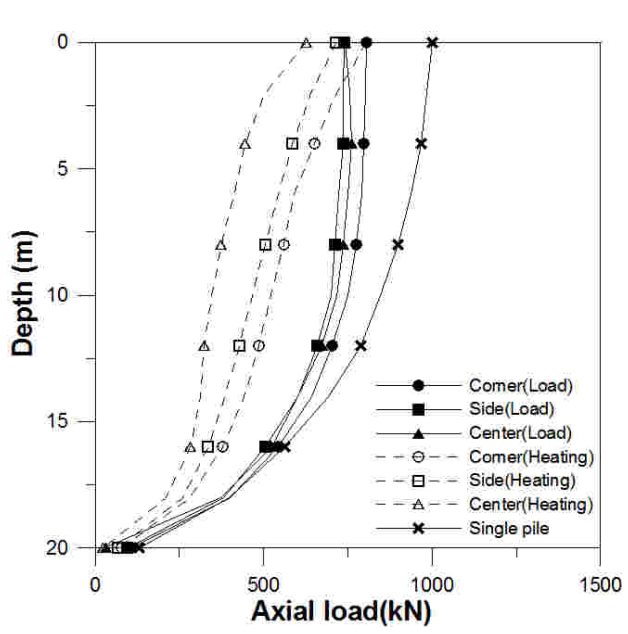

(a) Winter

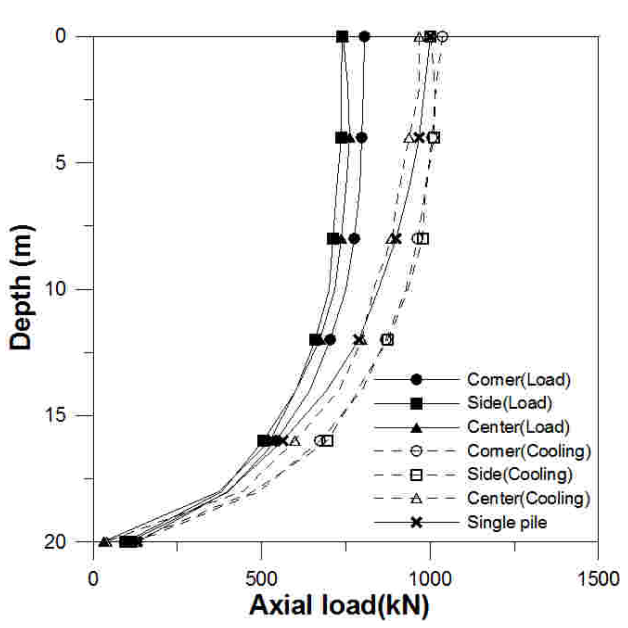

(b) Summer

Fig. 8. Effect of pile spacing on axial load distribution in sand $(3 \times 3,5 d)$ 
로 온도변화가 없는 경우, 말뚝의 모서리부에서 $804.2 \mathrm{kN}$ 으로 하중을 가장 크게 받으며, 측면부는 $741.9 \mathrm{kN}$, 중앙 부는 $737.9 \mathrm{kN}$ 으로 유사한 값을 가지며, 하절기시 말뚝 이 팽창하여 축하중이 증가하고, 동절기시 말뚝이 수축 하여 축하중이 감소하였다.

군말뚝 형태의 에너지파일의 경우, 열적영향만을 고 려하면 말뚝 간격이 증가할수록 말뚝 상호간의 열적 간

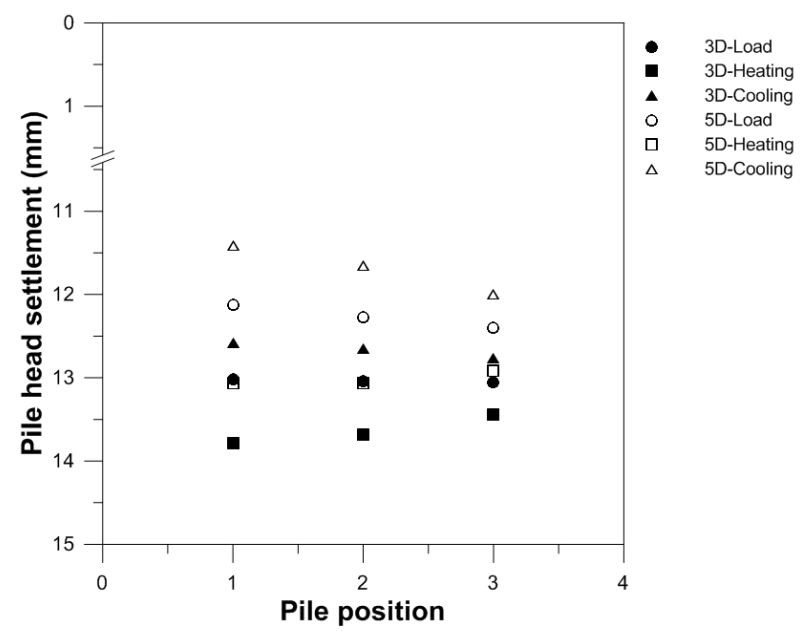

Fig. 9. Comparison of pile head settlement considering pile spacing in sand $(3 \times 3)$
섭이 감소하기 때문에 말뚝의 온도변화에 의한 축하중 의 변화가 작게 발생한다. 하지만 말뚝 중심 간격이 $3 \mathrm{D}$ 와 $5 \mathrm{D}$ 인 경우 말뚝 캡 상단에 동일한 하중이 작용하여 도, 말뚝 중심 간격이 커질수록 군말뚝내 개개말뚝들에 작용하는 말뚝 두부 하중은 서로 다르게 나타난다. 그 결과 열적영향과 작용하중에 의한 복합하중으로 Fig. 7, 8 과 같이 말뚝 간격이 커질수록 축하중의 변화가 크게 나타남을 알 수 있었다. Table 3 은 $3 \times 3$ 말뚝 배열에서 계 절 및 말뚝 간격에 따라 두부에서 받는 축하중의 크기를 정리한 것이다.

말뚝의 수축팽창 거동에 의해 두부에서 받는 축하중 의 크기가 증가 또는 감소되므로 말뚝의 두부 침하량을 산정하였으며, 산정 결과는 Fig. 9와 같다. 말뚝의 배치 에 따른 두부침하량을 분석한 결과, 동절기에는 말뚝이 수축을 하기 때문에 말뚝이 받는 축하중이 감소하며, 두 부침하량은 증가한다. 반대로 하절기에는 말뚝이 팽창 을 하기 때문에 말뚝이 받는 축하중은 증가하며, 두부침 하량은 감소하게 된다. 그리고 말뚝 배치에 따라 하중의 증감이 가장 크게 나타나는 모서리부에서 계절별 두부 침하량의 차이가 가장 크게 발생하며, 중앙부에서는 가 장 작게 나타났다.

\begin{tabular}{|c|c|c|c|c|}
\hline \multirow{2}{*}{ Season } & \multirow{2}{*}{ Pile spacing } & \multicolumn{3}{|c|}{ Pile position } \\
\hline & & (1) corner & (2) perimeter & (3) center \\
\hline \multirow{2}{*}{ Winter } & $3 \mathrm{D}$ & 851.4 & 768.4 & 451.3 \\
\hline & $5 \mathrm{D}$ & 865.8 & 785.5 & 626.5 \\
\hline \multirow{2}{*}{ Summer } & $3 D$ & 998.3 & 952.7 & 860.1 \\
\hline & $5 D$ & 1037.2 & 1000.6 & 968.1 \\
\hline
\end{tabular}

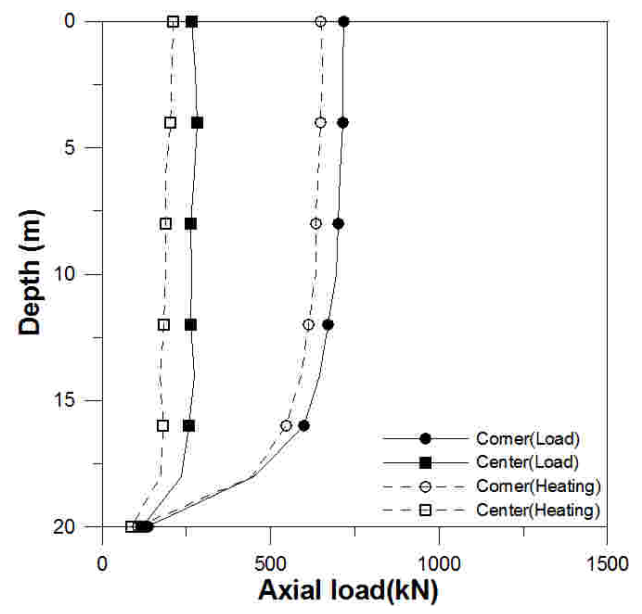

(a) Winter

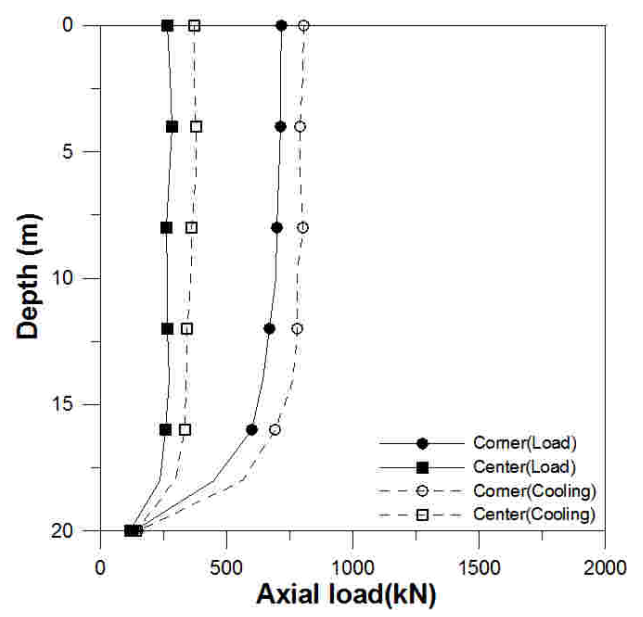

(b) Summer

Fig. 10. Effect of pile spacing on axial load distribution in sand $(5 \times 5,3 d)$ 


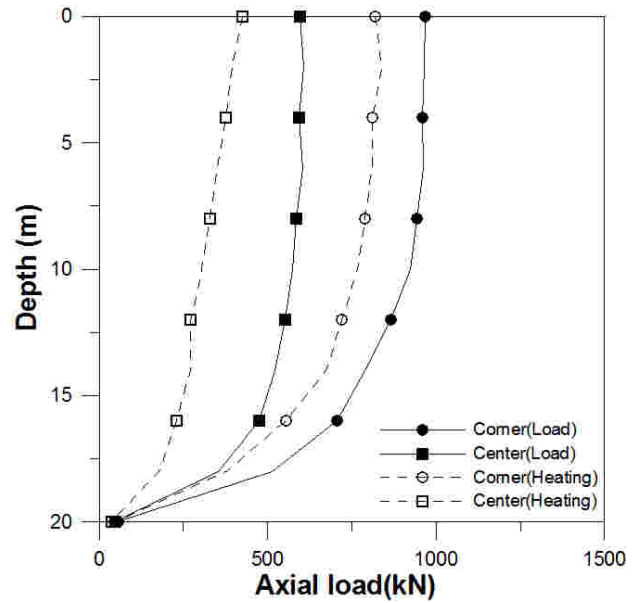

(a) Winter

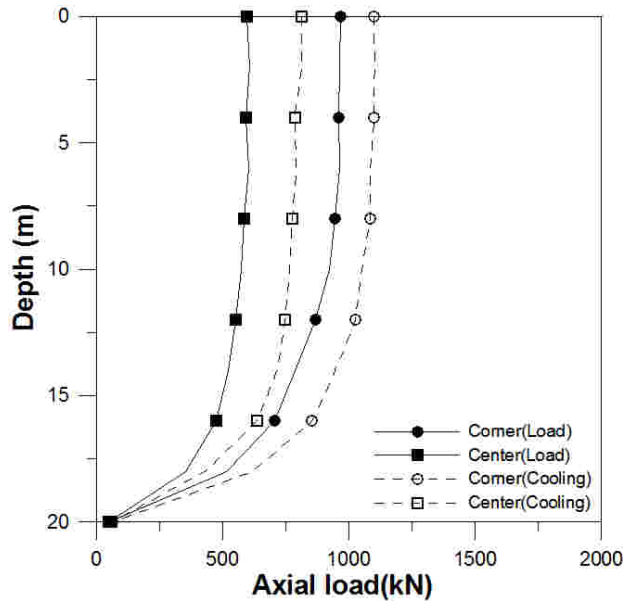

(b) Summer

Fig. 11. Effect of pile spacing on axial load distribution in sand $(5 \times 5,5 d)$

Table 4. Comparison of axial load considering relative pile spacings and positions in sand $(5 \times 5)$

(Unit : kN)

\begin{tabular}{c|c|c|c|c}
\hline \multirow{2}{*}{ Pile position Season } & \multicolumn{2}{|c|}{ Winter } & \multicolumn{2}{|c}{ Summer } \\
\cline { 2 - 5 } & 3D & 5D & 3D & 1010.0 \\
\hline (1) & 648.7 & 819.7 & 504.8 & 814.4 \\
\hline$(2)$ & 592.2 & 630.1 & 525.5 & 807.3 \\
\hline$(3)$ & 544.7 & 584.9 & 539.6 & 822.1 \\
\hline$(4)$ & 526.7 & 580.4 & 324.9 & 813.6 \\
\hline$(5)$ & 312.6 & 432.5 & 371.0 & 656.6 \\
\hline$(6$ & 210.6 & 262.6 & & \\
\hline
\end{tabular}

$5 \times 5$ 배열 군말뚝의 배치에 의한 하중전이양상을 확 인하기 위하여 Fig. 6(b)의 말뚝 중 모서리부에 위치한 1 번 말뚝과 중앙부에 위치한 6 번 말뚝을 대표로 선정하 여 축하중 분포를 산정하였다. 열응력에 의해 축하중이 증가 또는 감소되는 경향을 확인하였으며, 말뚝 간격이 넓어질수록 그 차이가 증가하였다. 말뚝 중심 간격이 $3 \mathrm{D}$ 일 때 모서리부와 중앙부 말뚝에서의 축하중 분포도 는 Fig. 10 과 같으며, 말뚝 중심 간격이 $5 \mathrm{D}$ 인 경우는 Fig. 11과 같다. Fig. 12는 말뚝의 위치별 두부 침하량을 나타낸 것이다. 또한, 모든 위치에서의 두부에 가해지는 하중의 크기를 산정하여 Table 4에 나타내었다.

일반적인 군말뚝의 경우, 역학적으로 말뚝중심 간격 이 일정할 때, 말뚝의 개수가 증가하게 되면, 주면마찰 력이 감소하는 경향을 보인다(백진열 등, 2012, 정상섬, $1993)$, 따라서 $3 \times 3$ 배열과 $5 \times 5$ 배열의 해석결과를 살펴보 면, $3 \times 3$ 배열인 경우, 주면마찰력의 영향이 $5 \times 5$ 배열보다 크기 때문에 말뚝 축하중이 깊이가 증가함에 따라 점차 적으로 감소하는 결과를 보인다. 반면에 $5 \times 5$ 배열인 경 우, 상대적으로 주면마찰력의 영향이 작기 때문에 축하

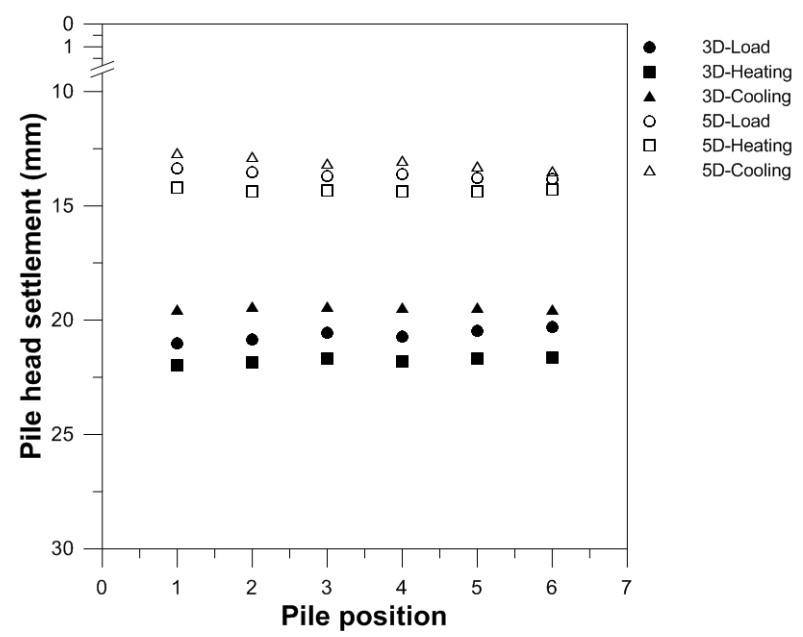

Fig. 12. Comparison of pile head settlement considering pile spacing in sand $(5 \times 5)$

중의 감소량이 작은 결과를 보인다.

\section{2 지반조건에 따른 거동 분석}

지반조건에 따른 영향을 분석하기 위하여 점성토 지 
반에서의 구조적 거동 분석을 수행하였다. 사질토 지반 의 동일한 조건으로 수행하였으며, 단독말뚝과 군말뚝 의 중심사이 간격 $(3 \mathrm{D}, 5 \mathrm{D})$ 에 따라 하중전이양상과 두부 침하량을 비교하였다. Fig. 13은 점성토 지반에서 $3 \times 3$ 배열 군말뚝의 중심 간격이 $3 \mathrm{D}$ 인 경우 축하중 분포를 나타내었으며, Fig. 14는 5D일 때의 축하중 분포이다. 말뚝 중심 간격이 $3 \mathrm{D}$ 인 경우 두부에 가해지는 축하중은 모서리부에서 $853 \mathrm{kN}$ 으로 가장 크게 나타났으며, 측면

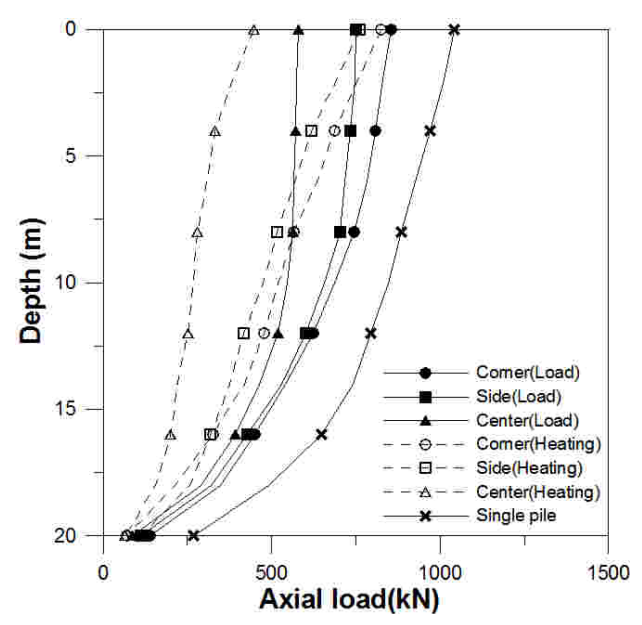

(a) Winter
부에서 $750 \mathrm{kN}$, 모서리부에서 $579 \mathrm{kN}$ 으로 나타났다. $5 \mathrm{D}$ 인 경우에는 모서리부 말뚝이 $855 \mathrm{kN}$ 이며, 측면부 말뚝 은 $758 \mathrm{kN}$, 중앙부 말뚝은 $727 \mathrm{kN}$ 로 산정되었다.

점성토 지반에서도 사질토 지반과 같이 에너지파일 의 온도변화에 의해 동절기에 축하중이 감소하고 하절 기에 증가하는 경향을 나타내었다. 이 때, 하절기에 두 부에 작용하는 축하중은 $3 \mathrm{D}$ 인 경우에 약 $20 \%$ 증가하였 고, $5 \mathrm{D}$ 인 경우 약 $25 \%$ 증가하여 말뚝 중심 간격이 증가

Fig. 13. Effect of pile spacing on axial load distribution in clay $(3 \times 3,3 d)$

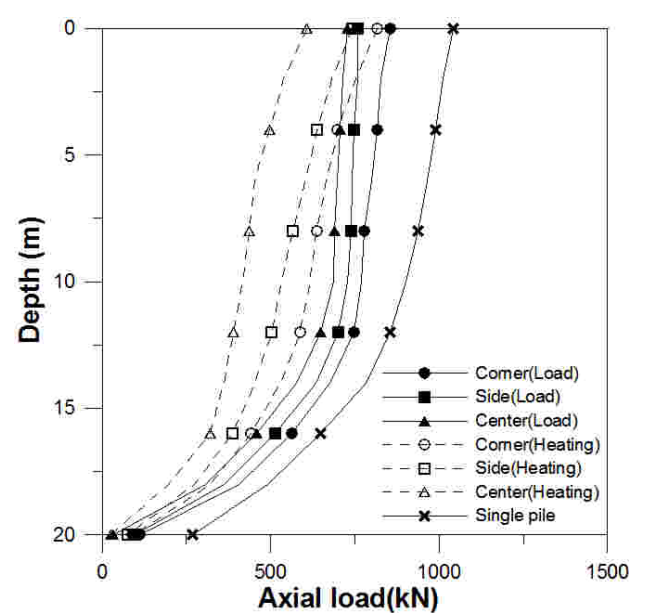

(a) Winter

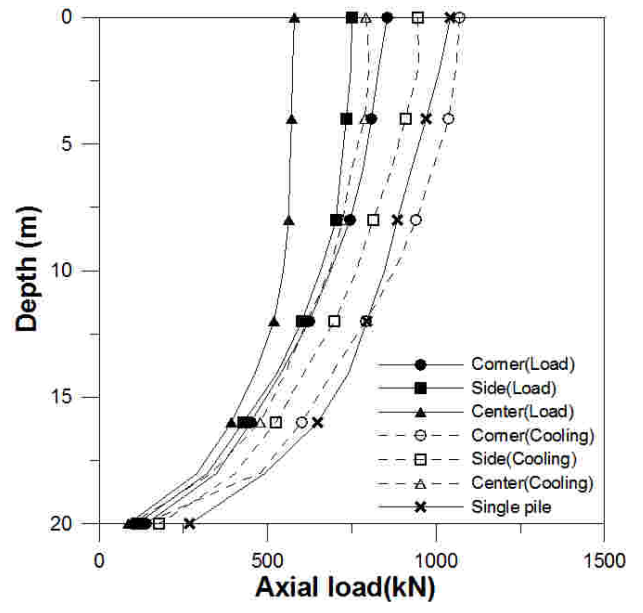

(b) Summer

Fig. 14. Effect of pile spacing on axial load distribution in clay $(3 \times 3,5 d)$

Table 5. Comparison of axial load considering relative pile spacings and positions in clay $(3 \times 3)$

(Unit : kN)

\begin{tabular}{c|c|c|c|c}
\hline \multirow{2}{*}{ Season } & \multirow{2}{*}{ Pile spacing } & \multicolumn{3}{|c}{ Pile position } \\
\cline { 2 - 5 } & & (1) Corner & (2) Perimeter & (3) Center \\
\hline \multirow{2}{*}{ winter } & 3D & 824.2 & 762.2 & 445.9 \\
\cline { 2 - 5 } & 5D & 835.6 & 771.3 & 607.2 \\
\hline \multirow{2}{*}{ summer } & 3D & 1069.3 & 945.2 & 792.3 \\
\cline { 2 - 5 } & 5D & 1074.4 & 1021.3 & 966.1 \\
\hline
\end{tabular}




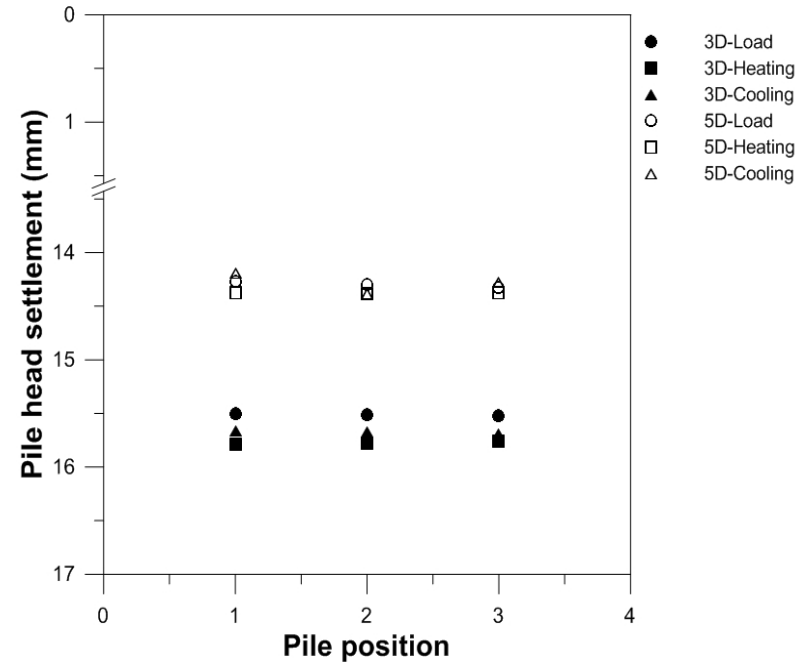

Fig. 15. Comparison of pile head settlement considering pile spacing in clay $(3 \times 3)$

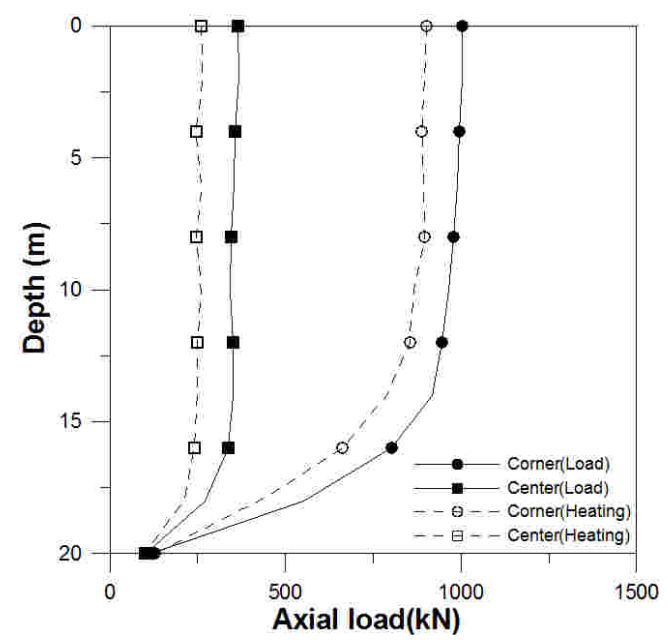

(a) Winter
할수록 하중변화량이 큰 것으로 판단되었다. 말뚝의 배 치 별 두부에 가해지는 하중의 크기는 Table 5에 정리하 였다. 동절기에 발생하는 추가 인장응력으로 인해 말뚝 의 지지력이 감소하여 두부침하량이 증가하게 된다. 점 성토 지반에서의 두부침하량은 사질토 지반에 비해 약 $1.5 \sim 3 \mathrm{~mm}$ 정도 크게 발생하였으며, 계절별 말뚝의 수 축팽창 거동에 따른 침하량의 차이가 거의 나타나지 않 았다. 또한 사질토 지반에 비해 모서리부와 측면부, 중 앙부에 위치한 말뚝 배치 별 침하량의 차이도 거의 나타 나지 않음을 확인하였다. 점성토 지반에서의 말뚝 두부 침하량은 Fig. 15 와 같다.

Fig. 16은 점성토 지반에서 $5 \times 5$ 배열 군말뚝의 중심 간격이 $3 \mathrm{D}$ 일 때에 축하중 분포를 나타낸 것이고, 말뚝 중 심 간격이 5D일 때에 축하중 분포는 Fig. 17에 나타냈다.

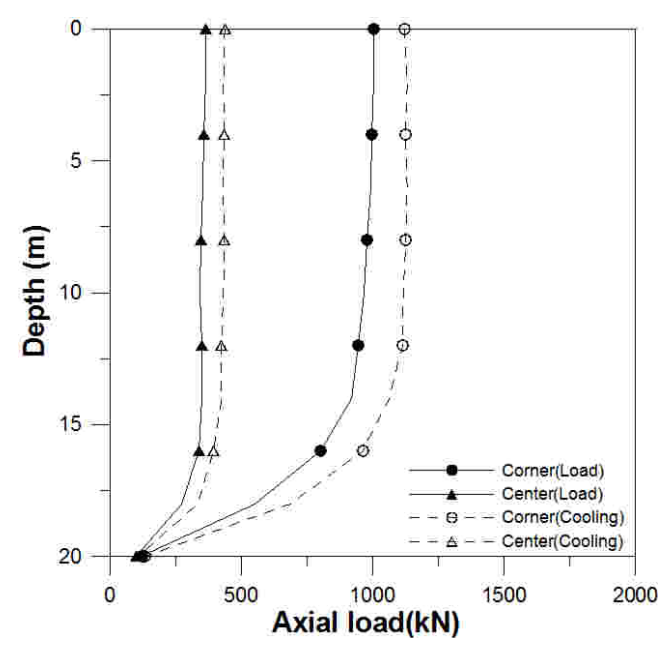

(b) Summer

Fig. 16. Effect of pile spacing on axial load distribution in clay $(5 \times 5,3 d)$

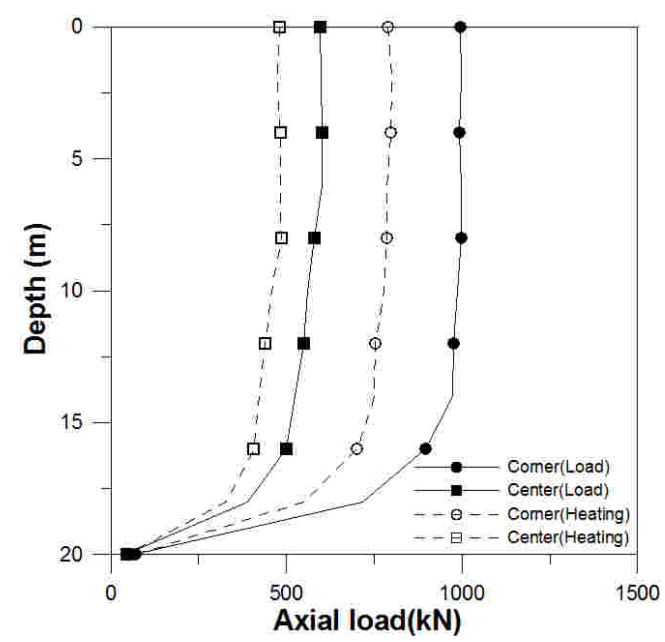

(a) Winter

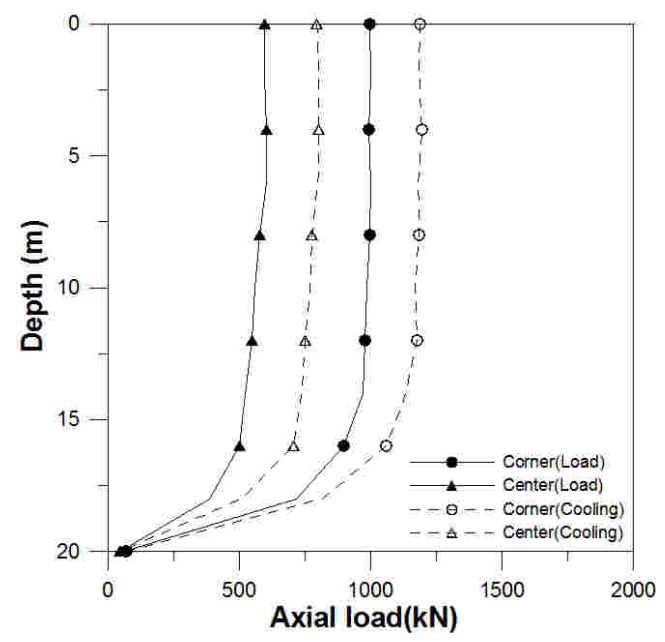

(b) Summer

Fig. 17. Effect of pile spacing on axial load distribution in clay $(5 \times 5,5 d)$ 


\begin{tabular}{c|c|c|c|c}
\hline \multirow{2}{*}{ Pile position } & \multicolumn{2}{|c|}{ winter } & \multicolumn{2}{|c}{ summer } \\
\cline { 2 - 5 } & $3 \mathrm{D}$ & $5 \mathrm{D}$ & $3 \mathrm{D}$ & 1085.5 \\
\hline (1) & 807.6 & 789.1 & 1020.2 & 931.3 \\
\hline$(2)$ & 702.8 & 734.3 & 590.8 & 802.4 \\
\hline$(3$ & 739.1 & 863.1 & 512.8 & 889.0 \\
\hline$(4)$ & 805.0 & 881.6 & 550.9 & 472.7 \\
\hline$(5)$ & 318.0 & 395.8 & 144.3 & 795.9 \\
\hline$(6$ & 256.6 & 480.9 & 436.3 & \\
\hline
\end{tabular}

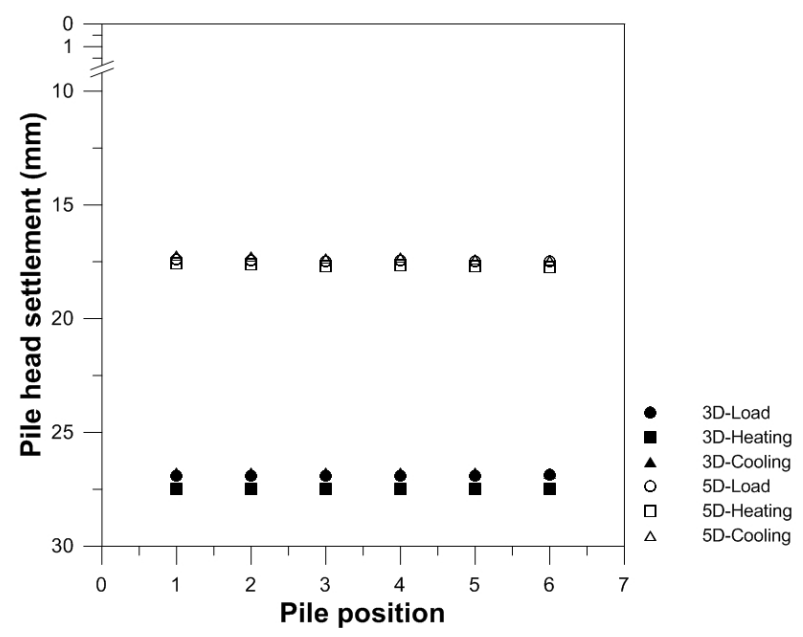

Fig. 18. Comparison of pile head settlement considering pile spacing in clay $(5 \times 5)$

말뚝의 배치 별 두부에 가해지는 하중의 크기는 Table 6에 정리하였다. 점성토 지반에서의 말뚝 위치별 두부침 하량은 Fig. 18 과 같다. 말뚝 간격이 $3 \mathrm{D}$ 와 $5 \mathrm{D}$ 일 때 모두 하절기에는 침하량이 감소하고 동절기에는 증가하였으 며, 점성토 지반은 또한 말뚝 간격이 $5 \mathrm{D}$ 인 경우보다 $3 \mathrm{D}$ 일 때 침하량이 약 $10 \mathrm{~mm}$ 크게 발생하였지만, 온도변화에 의 한 침하량의 차이는 미미하게 나타나 사질토 지반에 비해 상대적으로 온도변화에 의한 영향을 적게 받는 것을 확인 하였다. 또한 사질토 지반에 비해 같은 말뚝 배치와 응력 조건 에서 침하량이 약 $5 \mathrm{~mm}$ 크게 발생함을 확인하였다.

\section{3 선단지지조건에 따른 거동 분석}

Fig. 19와 같이 말뚝 선단이 암반에 지지된 경우 선단 지지력이 증가하므로 암반에 지지되지 않은 경우보다 상대적으로 말뚝 두부침하량이 감소한다. Fig. 20은 선 단지지조건에 따른 말뚝 배치별 두부침하량을 나타낸 것이다. 암반에 지지된 경우 모든 말뚝 배치에서 두부침 하량이 암반에 지지되지 않은 경우 보다 $1 / 3$ 로 감소하였

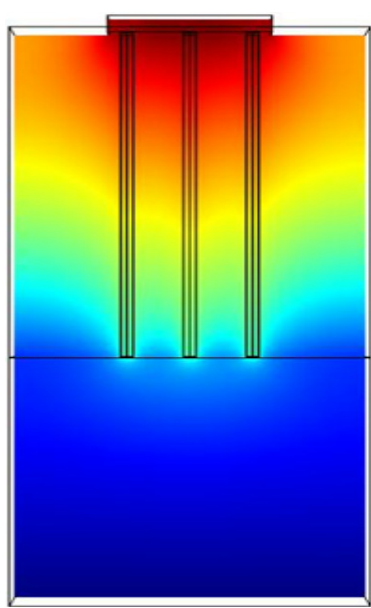

(a) End-bearing pile

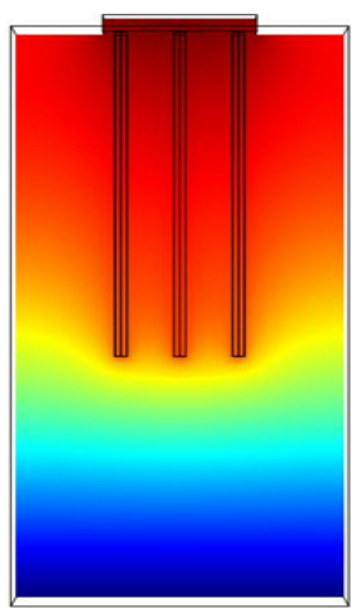

(b) Friction pile
Fig. 19. End-bearing conditions

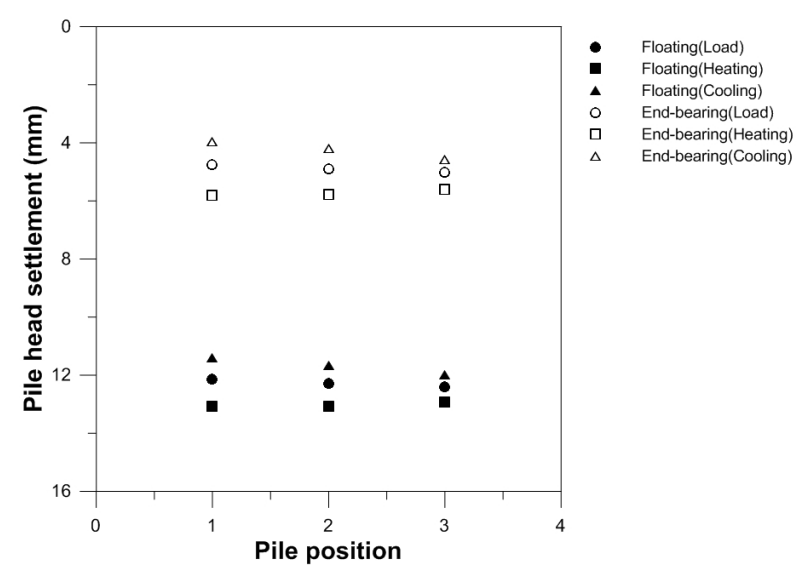

Fig. 20. Comparison of pile head settlement considering endbearing conditions

으나, 열응력에 의한 영향은 유사함을 보였다.

말뚝 배치에 따른 축하중 분포를 비교하기 위하여 모 서리부와 중앙부의 말뚝을 선정하여 선단지지조건에 따른 축하중 분포를 비교하였다. 모서리부와 중앙부의 축하중 분포도는 Fig. 21,22 와 같다. 해석 결과, 암반에 지지되는 경우 말뚝 선단부가 암반의 지지되지 않는 경 우 보다 구속되어 있기 때문에, 열응력에 의한 축하중의 


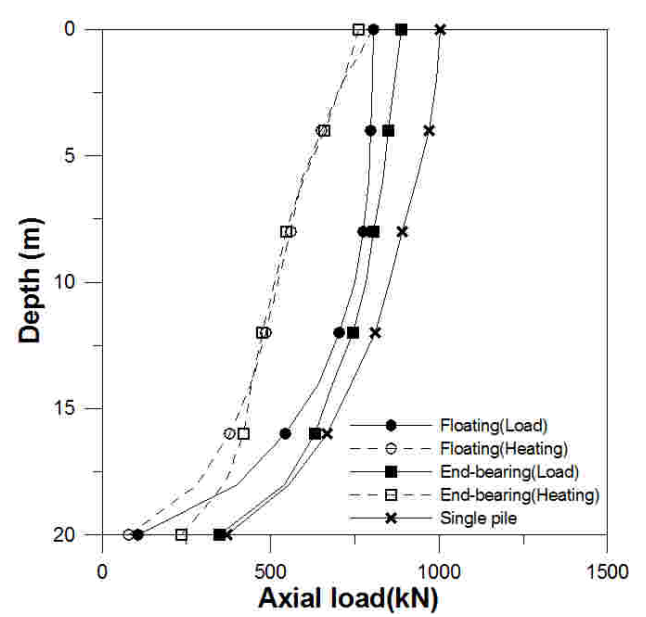

(a) Winter

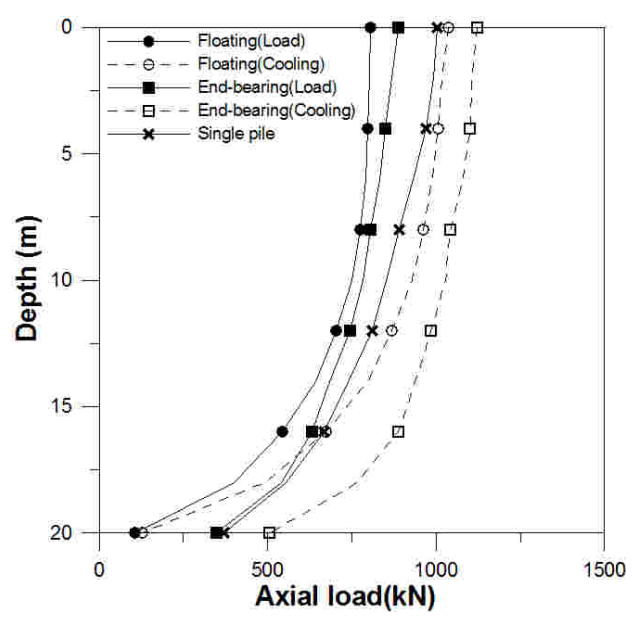

(b) Summer

Fig. 21. Effect of end-bearing conditions on axial load distribution for corner energy piles

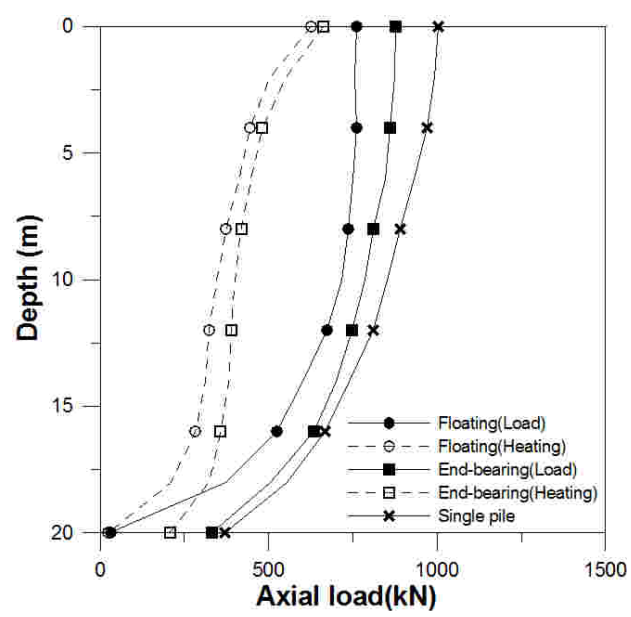

(a) Winter

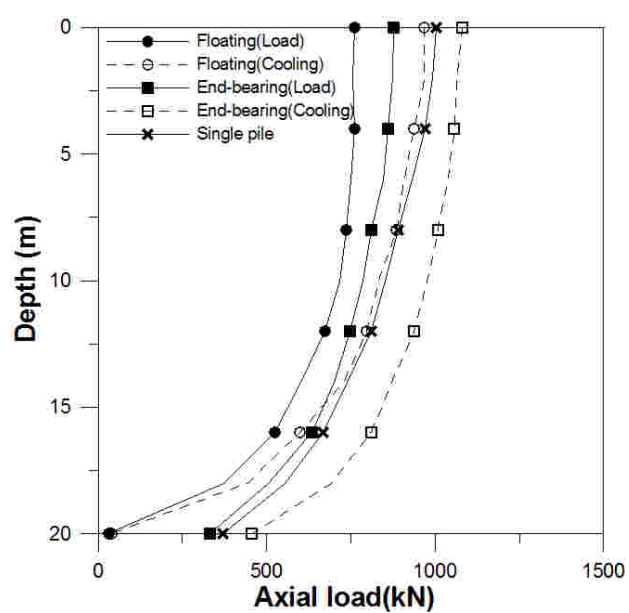

(b) Summer

Fig. 22. Effect of end-bearing conditions on axial load distribution for center energy piles

차이가 크게 발생하였다.

\section{4 말뚝 캡 강성도에 따른 거동 분석}

캡 강성도에 따른 침하량 분석 결과는 Fig. 23과 같다. 말뚝 캡이 연성인 경우 말뚝의 수축팽창 거동에 따른 침하량의 차이는 모서리부에서 가장 크게 발생하며, 말 뚝 배치별 침하량의 차이도 발생하는 것을 확인하였다. 하지만 말뚝 캡이 강성인 경우 캡의 강성이 매우 크므로 말뚝 배치에 따른 영향을 거의 받지 않으며 모두 동일한 크기의 침하량이 발생하였다.

\section{5. 결 론}

본 논문에서는 에너지파일 내 열 유체의 흐름에 따른

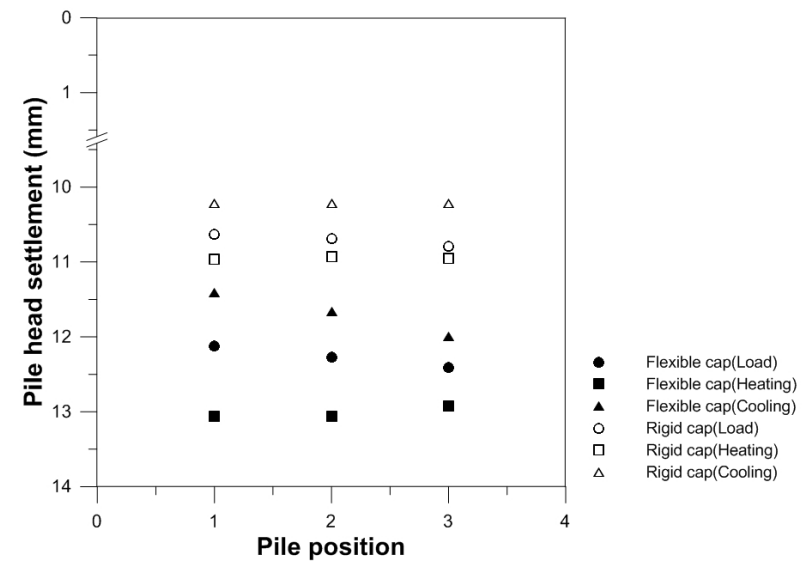

Fig. 23. Comparison of pile head settlement considering stiffness of raft

단기간 동안 말뚝의 수축팽창 거동을 고려하여 말뚝의 배열 및 배치에 따른 구조적 거동을 분석하였다. 지반조 
건, 계절조건에 따른 거동 차이를 분석하였으며, 말뚝 캡의 강성도, 선단지지조건에 따른 거동 변화를 확인하 였다. 연구수행결과는 다음과 같다.

(1) 에너지파일이 내부 순환수의 온도에 의해 말뚝은 수 축팽창 거동을 하여 축하중 분포가 변하게 된다. 동절 기에 에너지파일이 수축거동을 하면 축하중이 감소하 게 되고, 두부침하량은 증가함을 확인하였다. 반대로 하절기에 에너지파일이 팽창거동을 하는 경우에는 축 하중이 증가하며 두부침하량은 감소함을 확인하였다.

(2) 군말뚝 형태의 에너지파일에서 말뚝 중심 간격이 $3 \mathrm{D}, 5 \mathrm{D}$ 에 따른 해석 결과, 열적영향만 고려할 때와 달리 작용하중과의 복합하중으로 말뚝 중심 간격이 클수록 온도변화에 따른 말뚝의 축하중 차이가 크 게 나타남을 알 수 있었다. 또한, 말뚝 배치별 분석 결과, 모서리부 말뚝의 축하중 차이가 가장 크게 발 생하는 것을 확인하였다.

(3) 군말뚝의 선단이 암반에 지지된 경우, 암반에 지지 되지 않은 경우보다 말뚝 선단부의 온도변화에 의 한 하중변화가 더 크게 발생하였으며, 전체침하량 은 약 $1 / 3$ 로 감소하였으나 열응력에 의한 영향은 유 사함을 확인하였다. 또한 말뚝 캡의 강성이 커질수 록 온도변화에 의한 침하량의 차이가 감소하였다.

\section{감사의 글}

본 연구는 한국전력공사 주력연구과제로 수행된 “에 너지파일을 활용한 변전소 냉난방 표준설계시스템 개 발" 과제의 위탁연구에 대한 지원과 2011년도 정부(교 육과학기술부)의 재원으로 한국연구재단의 지원(NO. 2011-0030842)을 받아 수행된 연구임.

\section{참 고 문 헌}

1. Baek, S.K. (2004), A Study on geothermal heat pump system utilizing hollow piles, Doctoral Dissertation, Pusan National University.

2. Bourne-Webb, B. Amatya, K. Soga, T. Amis, C. Davidson, and P. Payne (2009), "Energy pile test at Lambeth College, London: geotechnical and thermodynamic aspects of pile response to heat cycles", Geotechnique, Vol.59, Issue 3, pp.237-248.

3. COMSOL Multiphysics user's guide (2011), COMSOL Multiphysics version $4.2 a$.

4. Knellwolf, C., Peron, H., and Laloui. L. (2011), "Geotechnical analysis of heat exchanger piles", Journal of Geotechnical And Geoenvironmental Engineering, Vol.137, No.10, pp.890-902.
5. Engineeringtoolbox.com, 2005.

6. Environmental Protection Agency (1993), Health Effects of Passive Smoking : Lung Cancer and Other Disorders.

7. Hamada, Y., Saitoh, H., Nakamura, M., Kubota, H., and Ochifuji. K. (2007), "Field performance of an energy pile system for space heating", Energy and Buildings 39, pp.517-524.

8. Horikoshi, K. and Randolph, M.F. (1997), "On the definition of raft-soil stiffness ratio", Geotechnique, Vol.47, No.5, pp.1055-1061.

9. Jeong, S.S. (1993), "Downdrag on a single pile and pile groups", Journal of the Korea Civil Engineers Society, Vol.13, No.4, pp. 259-268.

10. Jeong, S.S., Song, J.Y., Min, H.S., and Lee, S.J. (2010), "Thermal influential factors of energy pile", Journal of the Korea Civil Engineers Society, Vol.30, No.6C, pp.231-239.

11. Kim, Y.H. and Jeong, S.S. (2011), "Analysis of soil resistance on laterally loaded piles based on 3D soil-pile interaction", Computers and Geothechnics, Vol.38, No.2, pp.248-257.

12. Laloui, L., Moreni, M., Fromentin, A., Pahud, D., and Vulliet, L. (1999), "In-situ thermo-mechanical load test on a heat exchanger pile", 4th International Conference on DEEP FOUNDATION PRACTICE, pp.273-279.

13. Ministry of Land, Infrastructure and Transport (2010), Development of closed vertical loop ground heat exchanger systems for utilizing geothermal heating and cooling system, Ministry of Land, Infrastructure and Transport.

14. Ministry of Trade, Industry and Energy (2006), The Development of Ground Heat Exchangers that are More Efficiency and Lower Price, Ministry of Trade, Industry and Energy.

15. Min, H.S., Yun, T.S., and Jeong, S.S. (2011), "Effect of group spacing of energy piles on thermal analysis", Journal of the Korean Geotechnical Society, Vol.27, No.8, pp.39-50.

16. Min, S.H., Lee, C.H., Park, M.S., Koh, H.S., and Choi, H.S. (2010), "Numerical study of heat transfer efficiency, performance and mechanical behavior induced by thermal stress of energy Pile", Journal of Korea Society of Geothermal Energy Engineers, Vol.6, No.2, pp.9-13.

17. Paek, J.Y., Cho, J.Y., Jeong, S.S., and Hwang, T.J. (2012), "Shaft group efficiency of friction pile groups in deep soft clay", Journal of the Korea Civil Engineers Society, Vol.32, No.2C, pp.49-60.

18. Song, J.Y. (2011), A Study on the Influence Factors of PHC Energy Piles based on Thermal and Structural Characteristics, Master's Dissertation, Yonsei University.

19. Wallace, J. W., Fox, P. J., and Stewart, J. P. (2002), “A simplified approach for settlement analysis of single pile and pile groups considering interaction between identical piles in multilayered soils", Computers and Geotechnics, Vol.27, No.8, pp.969-976.

20. Woo, S.W., Kim, J.H., Shin, S.H., and Hwang, K.I. (2007), "The Comparison of the EWT and LWT between Field Measurement and CFD of Vertical-type Geothermal Heat Exchanger", Journal of Korea Society of Geothermal Energy Engineers, Vol.3, No.1, pp.11-16.

21. Yu, H.K. (2008), "Development and Performance Evaluation of Ground Heat Exchanger Utilizing PHC Pile Foundation of Building", Journal of the Korean Solar Energy Society, Vol.28, No.5, pp. 56-64.

(접수일자 2012. 10. 24, 심사완료일 2013. 5. 2) 